\title{
Two new dottyback species of the genus Pseudochromis from southern Indonesia (Teleostei: Pseudochromidae)
}

\author{
ANTHONY C. GILL ${ }^{1,2}$, GERALD R. ALLEN ${ }^{3} \&$ MARK ERDMANN ${ }^{4}$ \\ ${ }^{\prime}$ Macleay Museum and School of Biological Sciences, A12 - Macleay Building, The University of Sydney, New South Wales 2006, Aus- \\ tralia.E-mail: Anthony.c.gill@sydney.edu.au \\ ${ }^{2}$ Ichthyology, Australian Museum, 6 College Street, Sydney, New South Wales 2010, Australia \\ ${ }^{3}$ Western Australian Museum, Locked Bag 49, Welshpool DC, Perth, Western Australia 6986, Australia \\ ${ }^{4}$ Conservation International, Jl. Dr. Muwardi No. 17, Denpasar, Bali 80235 Indonesia
}

\begin{abstract}
Pseudochromis oligochrysus new species is described from nine specimens collected from Nusa Penida (off Bali) and Pura Island (between Pantar and Alor), Indonesia. It resembles P. flavopunctatus Gill \& Randall from Komodo, Indonesia, but differs in live coloration and scale counts. Pseudochromis rutilus new species is described from the holotype collected from Nusa Penida. It differs from similar species in being deeper bodied and in its distinctive live coloration.
\end{abstract}

Key words: Pseudochromidae, Pseudochromis oligochrysus new species, Pseudochromis rutilus new species, Indonesia, systematics

\section{Introduction}

Gill (2004) revised the Indo-Pacific fish subfamily Pseudochrominae, recognising 80 valid species in 10 genera. The vast bulk of species (57) were classified in Pseudochromis, a genus that remains undiagnosed cladistically and effectively serving as a catch-all for species that can not be placed in the remaining nine genera. Since publication of Gill's revision, ten additional species of Pseudochromis have been described, mostly based on recent collections from the highly diverse Coral Triangle area of the West Pacific (Gill \& Allen 2004, 2011; Allen et al. 2008; Gill et al. 2009, in press; Gill \& Williams 2011; Gill \& Zajonz 2011). We herein describe two additional new species of the genus, which were collected in southern Indonesia during recent Conservation International sponsored surveys by the second and third authors.

\section{Material and methods}

Methods of counting, measuring and presentation follow Gill (2004). Institutional codes are as follows: AMS Australian Museum, Sydney; MZB-Museum Zoologicum Bogoriense, Cibinong, Indonesia; WAM-Western Australian Museum, Perth. Comparisons with other species are based on specimens listed in Gill (2004). Frequencies for meristic characters are given in Table 1.

\section{Pseudochromis oligochrysus sp. nov.}

Gold-ring Dottyback

Figures 1-3; Table 1

Holotype. MZB 20567, 49.8 mm SL, Indonesia, Nusa Penida, Mangrove Point, 0840’S 115²8’E, 45-50 m, M.V. Erdmann, 8 May 2008. 


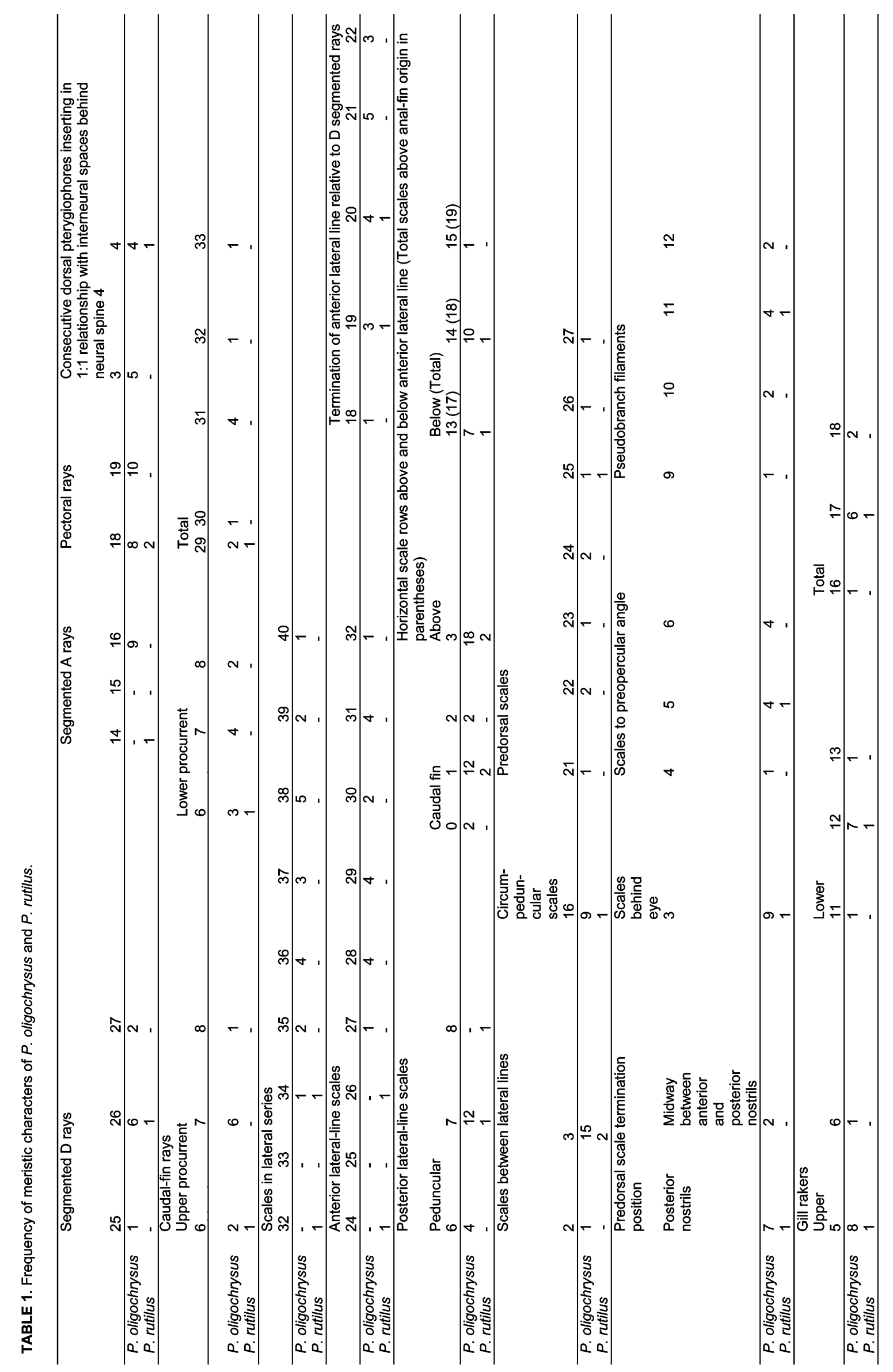


Paratypes. WAM P.33099-003, 2: 50.0-57.0 mm SL, Indonesia, Nusa Penida, Mangrove Point, 0840’S 115 28'E, 60-70 m, M.V. Erdmann, 21 November 2008; WAM P.33101-002, 2: 49.5-50.8 mm SL, Indonesia, Nusa Penida, Crystal Bay South, 0843'S 115²7’E, 25-50 m, M.V. Erdmann, 26 November 2008; AMS I.45680001, 1: $47.0 \mathrm{~mm}$ SL, collected with holotype; WAM P.33016-001, 1: $40.5 \mathrm{~mm}$ SL, collected with holotype; WAM P.33399-001, 2: 45.2-52.6 mm SL, Indonesia, Pantar Strait, Pura Island, 08 ${ }^{\circ} 19^{\prime} \mathrm{S} 124^{\circ} 22^{\prime} \mathrm{E}, 40 \mathrm{~m}$, M.V. Erdmann, 26 March 2011.

Diagnosis. A species of Pseudochromis with the following combination of characters: dorsal-fin rays III,2527, usually III,26; anal-fin rays III,16; circumpeduncular scales 16; horizontal scale rows above anal-fin origin 13$15+1+3=17-19$; predorsal scales 21-27; caudal fin rounded; dark spot on upper part of pectoral-fin base; and yellow spots or markings on anterior body.

Description (based on nine specimens, 40.5-57.0 $\mathrm{mm} \mathrm{SL}$; data for all types followed, where variation was noted, by data for holotype in parentheses; counts recorded bilaterally from the holotype are given separated by a slash, firstly the left side). Dorsal-fin rays III,25-27 (III,27), all segmented rays branched; anal-fin rays III,16, all segmented rays branched; pectoral-fin rays 18-19 (19/19); upper procurrent caudal-fin rays 6-8 (7); lower procurrent caudal-fin rays 6-8 (6); total caudal-fin rays 29-33 (30); scales in lateral series 34-40 (36/35); anterior lateral-line scales 27-32 (28/28); anterior lateral line terminating beneath segmented dorsal-fin ray 18-22 (21/21); posterior lateral-line scales $6-7+0-2(6+1 / 6+0)$; scales between lateral lines $2-3(3 / 3)$; horizontal scale rows above anal-fin origin $13-15+1+3=17-19(13+1+3 / 13+1+3)$; circumpeduncular scales 16 ; predorsal scales 21-27 (22); scales behind eye 3; scales to preopercular angle 4-6 (5); gill rakers 5-6 + 11-13 = 16-18 $(5+12)$; pseudobranch filaments 9-12 (11); circumorbital pores 23-32 (27/28); preopercular pores 10-13 (12/13); dentary pores 4; posterior interorbital pores 1-2 (2).

Lower lip incomplete, with weak to moderate symphyseal interruption; dorsal and anal fins without scale sheaths, although sometimes with intermittent scales overlapping fin bases; predorsal scales extending anteriorly to point ranging from posterior nostrils to midway between posterior and anterior nostrils; opercle with 4-6 relatively indistinct serrations; teeth of outer ceratobranchial-1 gill rakers well developed only on tips; anterior dorsal-fin pterygiophore formula $\mathrm{S} / \mathrm{S} / \mathrm{S}+3 / 1+1 / 1 / 1 / 1 / 1+1 * / 1(\mathrm{~S} / \mathrm{S} / \mathrm{S}+3 / 1+1 / 1 / 1 / 1 / 1+1 / 1)$; dorsal-fin spines moderately stout to stout and pungent; anterior anal-fin pterygiophore formula $3 / 1+1 / 1+1 * / 1(3 / 1+1 / 1 / 1+1)$; anal-fin spines moderately stout to stout and pungent, second spine stouter than third; pelvic-fin spine moderately stout to stout and pungent; second segmented pelvic-fin ray longest or subequal to third; caudal fin rounded; vertebrae $10+$ 16; epineurals 13-14 (14); epurals 3.

Upper jaw with 2-4 pairs of curved, enlarged caniniform teeth anteriorly, and 5-6 (at symphysis) to 2-3 (on sides of jaw) inner rows of small conical teeth, outermost of rows of conical teeth much larger and more curved than inner rows; lower jaw with 1-3 pairs of curved, enlarged caniniform teeth anteriorly, and 4-6 (at symphysis) to 1 (on sides of jaw) inner rows of small conical teeth, teeth on middle of jaw slightly larger and curved; vomer with 1-3 rows of small conical teeth, forming chevron; palatines with 1-3 rows of small conical teeth arranged in elongate, suboval patch, anterior part of tooth patch more-or-less contiguous with posterolateral arm of vomerine tooth patch; ectopterygoid edentate; tongue moderately pointed and edentate.

As percentage of SL: head length 22.6-28.4 (24.7); orbit diameter 8.9-10.6 (9.6); snout length 5.8-6.9 (6.0); fleshy interorbital width 5.9-6.8 (6.6); bony interorbital width 4.2-5.3 (4.8); body width 12.0-14.4 (13.1); snout tip to posterior tip of retroarticular bone 13.5-15.0 (13.5); predorsal length 31.5-35.3 (32.3); prepelvic length 29.332.8 (29.3); posterior tip of retroarticular bone to pelvic-fin origin 16.5-20.7 (16.5); dorsal-fin origin to pelvic-fin origin 29.1-32.3 (31.3); dorsal-fin origin to middle dorsal-fin ray 33.7-39.1 (36.9); dorsal-fin origin to anal-fin origin 42.0-45.1 (44.2); pelvic-fin origin to anal-fin origin 26.0-33.2 (31.3); middle dorsal-fin ray to dorsal-fin termination 23.5-27.7 (25.7); middle dorsal-fin ray to anal-fin origin 26.6-29.8 (29.1); anal-fin origin to dorsal-fin termination 35.1-38.0 (35.3); anal-fin base length 26.7-31.4 (28.1); dorsal-fin termination to anal-fin termination 14.6-16.9 (16.7); dorsal-fin termination to caudal peduncle dorsal edge 9.9-12.3 (11.0); dorsal-fin termination to caudal peduncle ventral edge 18.6-20.5 (20.3); anal-fin termination to caudal peduncle dorsal edge 19.9-21.4 (21.1); anal-fin termination to caudal peduncle ventral edge 11.2-12.8 (12.4); first dorsal-fin spine 1.8-3.0 (2.2); second dorsal-fin spine 4.2-6.2 (4.8); third dorsal-fin spine 6.6-8.6 (6.8); first segmented dorsal-fin ray 9.1-12.8 (10.4); fourth last segmented dorsal-fin ray 15.9-17.9 (16.3); first anal-fin spine 1.4-3.0 (3.0); second anal-fin spine 3.4-6.0 (5.0); third anal-fin spine 4.8-7.2 (broken); first segmented anal-fin ray 9.0-12.1 (9.0); fourth last segmented anal-fin ray 13.8-17.3 (14.1); third pectoral-fin ray 13.8-16.8 (14.5); pelvic-fin spine 9.3-11.9 (10.2); second segmented pelvic-fin ray 19.9-23.8 (21.1); caudal-fin length 23.0-28.3 (28.3). 
Live coloration (based on photographs of type specimens and other individuals from Nusa Penida and Pantar Strait when alive, Figures 1-3): head and body dark olive, becoming purplish grey ventrally and posteriorly; orbital rim narrowly bright yellow, this edged broadly posteriorly and ventrally with bluish to purplish grey curved bar; curved bar in turn edged with bright yellow curved bar or series of spots; remainder of cheek and operculum with pale to bright yellow spots, which sometimes align to form short bars or stripes; iris brown to orange with blue suboval ring around pupil; pectoral-fin base grey, becoming darker grey to black dorsally and in axil of fin; scales of anterior body each with pale yellow central spot; in some individuals (from Pantar Strait) yellow is brighter and confined to dorsal and ventral edges of scales, which combine with darker purplish grey remainder of scale to form alternating bright yellow and purplish grey stripes on anterior body; caudal peduncle and posterior part of body sometimes reddish brown to orange dorsally; dorsal-fin rays orange to yellow, the membranes olive-grey, sometimes becoming reddish brown to orange posteriorly and yellowish to orange-brown distally, with broad grey stripe through middle of fin; dark grey-blue spot behind base of each dorsal-fin ray; distal margin of dorsal fin narrowly bluish grey; anal fin pale blue to pale grey basally, the remainder of fin dark grey to blue grey, with one or two yellow stripes through basal half of fin and yellow stripe edging blue to blue-grey distal margin of fin; caudal fin dark purplish grey, broadly pale yellow to pale orange ventrally and dorsally, with bluish grey to blue distal margin; pectoral fins pinkish to reddish hyaline; pelvic fins bright yellow with anterior margin bluish grey to blue.

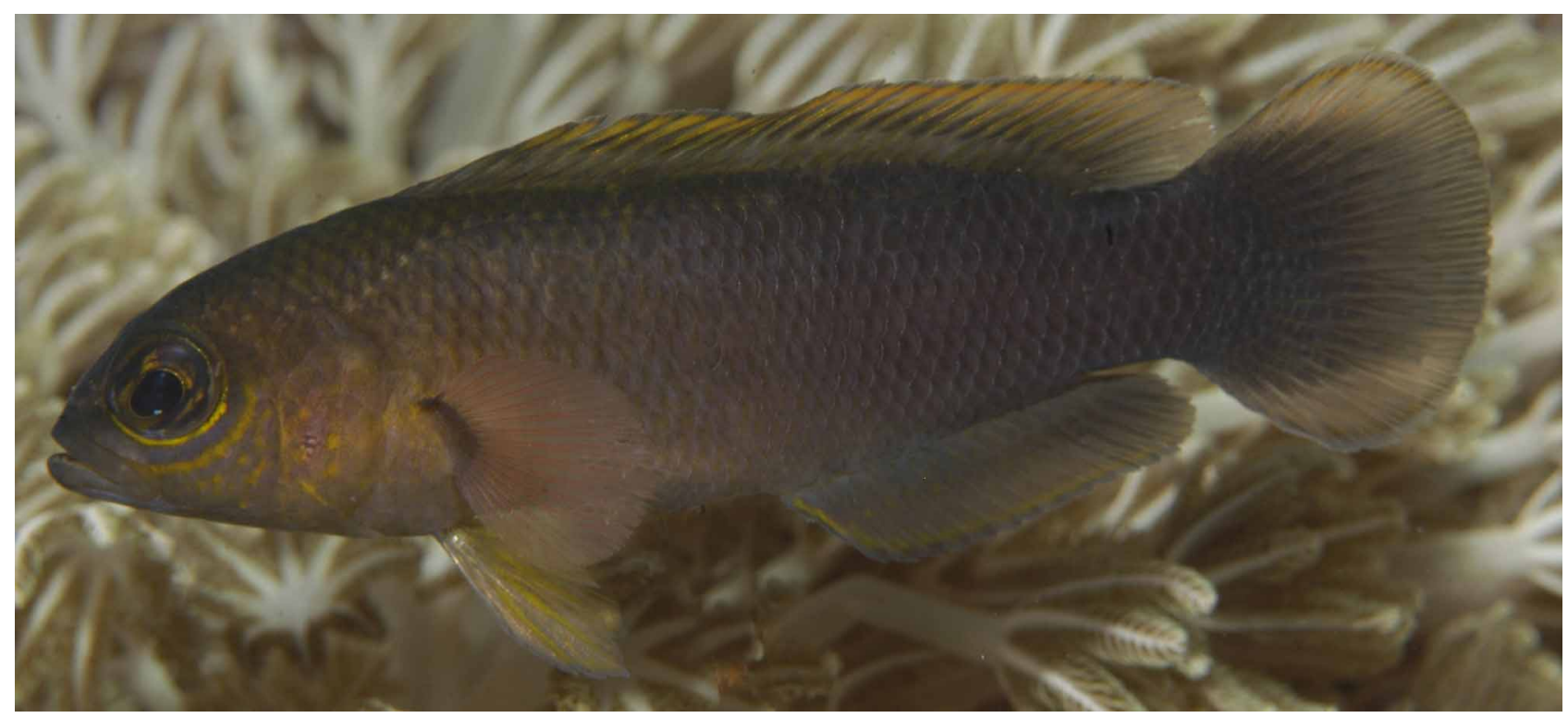

FIGURE 1. Pseudochromis oligochrysus, MZB 20567, holotype, 49.8 mm SL, Nusa Penida, Indonesia (photo by G.R. Allen).

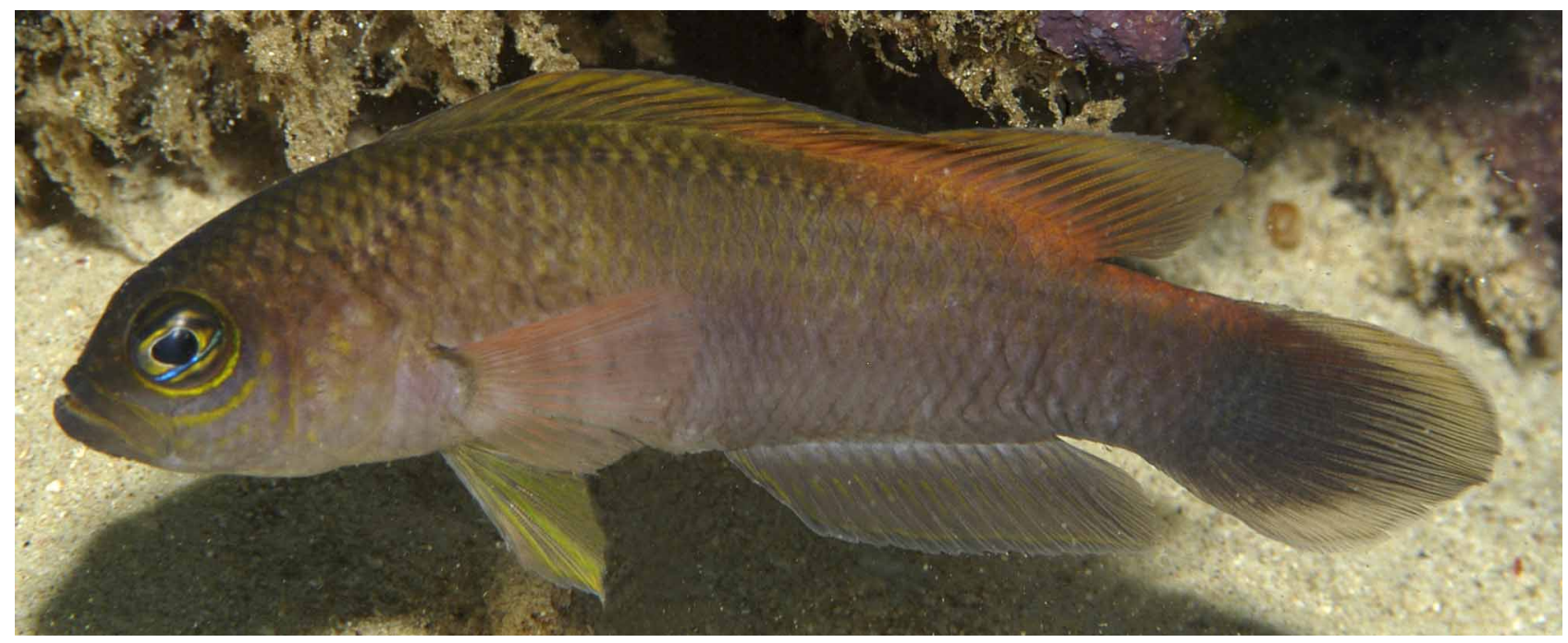

FIGURE 2. Pseudochromis oligochrysus, WAM P.33053-003, paratype, 57.0 mm SL, Nusa Penida, Indonesia (photo by G.R. Allen). 


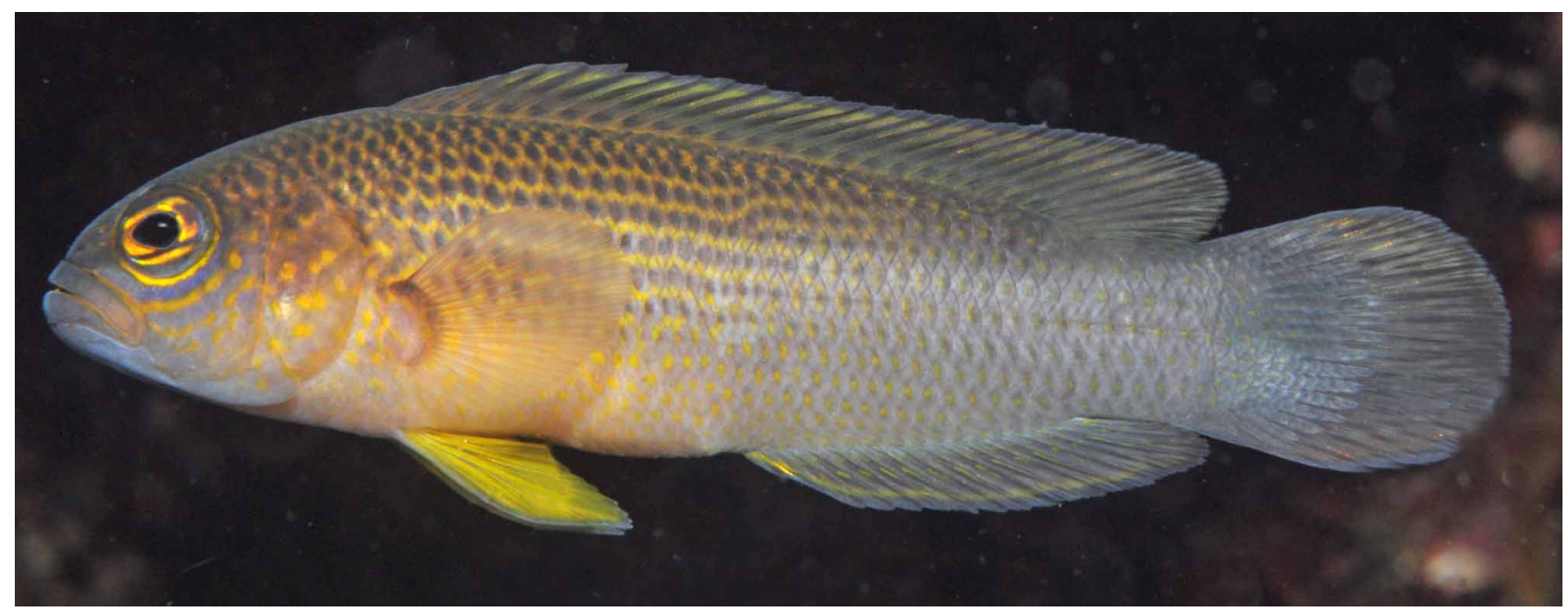

FIGURE 3. Pseudochromis oligochrysus, WAM P.33399-001, paratype, 52.6 mm SL, Pura Island, Pantar Strait, Indonesia (photo by G.R. Allen).

Preserved coloration: pattern similar to live coloration, head and body becoming grey-brown, paler ventrally on abdomen and lower head; yellow to orange markings remain, becoming pale brown to pale yellow; purplish to bluish grey or grey markings on head, anterior body and fins become dark grey-brown.

Habitat and Distribution. Pseudochromis oligochrysus is known only from a few scattered localities in the Lesser Sunda Islands of southern Indonesia, including Nusa Penida and Menjangan Islands off the coast of Bali and from Tanjung Watuili in south Pantar and Pura Island in the Pantar Strait, between Pantar and Alor. It was observed between 25 and $50 \mathrm{~m}$ depth (typically below $40 \mathrm{~m}$ ), exclusively on reefs subject to strong currents and frequent cold-water upwellings. The species was always found in association with coral overhangs or large rubble pieces on hard bottom substrates, and would retreat under the rubble or overhang when approached. Its habitat preferences seem very narrowly defined; in recent intensive surveys around the island of Bali the species was only observed at 4 of 47 sites surveyed (all on Nusa Penida and Menjangan islands) - each with strong currents, cold upwelling and hard bottoms.

Comparisons. Pseudochromis oligochrysus closely resembles P. flavopunctatus Gill and Randall (1998) in having the following combination of characters: segmented dorsal-fin rays 25-27, usually 26; segmented anal-fin rays 16; circumpeduncular scales 16; caudal fin rounded; dark spot on upper part of pectoral-fin base; and yellow spots or markings on anterior body. It is readily distinguished from P. flavopunctatus in have more horizontal scale rows scales above the anal-fin origin $(13-15+1+3=17-19$ versus $10-12+1+2-3=13-16)$ and more predorsal scales (21-27 versus 16-22). Moreover, the two species differ in live coloration details: yellow markings on the body scales of $P$. oligochrysus are present as indistinct pale spots or, when prominent, are confined to the upper and lower edges of the scales whereas in P. flavopunctatus they are present as prominent central spots; the pelvic fins are bright yellow in $P$. oligochrysus versus pale pink in P. flavopunctatus.

Using Gill's (2004) key to Pseudochromis species, P. oligochrysus falls in the couplet (51) distinguishing $P$. flavopunctatus from species in the remaining couplets (P. andamanensis Lubbock 1980, P. aurulentus Gill \& Randall 1998, P. litus Gill \& Randall 1998, P. marshallensis Schultz 1953, P. pylei Randall \& McCosker 1989, and $P$. reticulatus Gill \& Woodland 1992). It differs from all these species in having 16 segmented anal-fin rays (versus 11-15).

Remarks. The specific epithet is a combination of the Greek words ỏ $\lambda ı \gamma$ and $\chi \rho v \sigma o \zeta$ that means "having little gold", alluding to the scant though distinctive yellow markings of the species. When viewed underwater, the yellow markings around the eye are particularly obvious and distinctive, as are the bright yellow pelvic fins. 


\section{Pseudochromis rutilus sp. nov.}

Red-gold Dottyback

Figure 4, Table 1

Holotype. MZB 20568, 55.0 mm SL, Indonesia, Nusa Penida, Buyuk (0840’S 115³3’E), 65-70 m, M.V. Erdmann, 25 November 2008 (field number NP-08-12A).

Diagnosis. A species of Pseudochromis with the following combination of characters: dorsal-fin rays III,26; anal-fin rays III,14; circumpeduncular scales 16; dorsal-fin origin to pelvic-fin origin $34.7 \%$ SL; third anal-fin spine $7.1 \%$ SL.

Description (based on the holotype). Dorsal-fin rays III,26, all segmented rays branched; anal-fin rays III,14, all segmented rays branched; pectoral-fin rays 18/18; upper procurrent caudal-fin rays 6; lower procurrent caudal-fin rays 6; total caudal-fin rays 29; scales in lateral series 32/34; anterior lateral-line scales 24/26; anterior lateral line terminating beneath segmented dorsal-fin ray 19/20; posterior lateral-line scales $8+1 / 7+1$; scales between lateral lines $3 / 3$; horizontal scale rows above anal-fin origin $13+1+3 / 14+1+3$; circumpeduncular scales 16; predorsal scales 25; scales behind eye 3; scales to preopercular angle 5; gill rakers $5+12=17$; pseudobranch filaments 11; circumorbital pores 30/28; preopercular pores 10/9; dentary pores 4/4; posterior interorbital pores 2 .

Lower lip incomplete (interrupted at symphysis); dorsal and anal fins without scale sheaths, though with intermittent scales overlapping fin bases; predorsal scales extending anteriorly to midway between anterior and posterior nostrils; opercle with 4-5 indistinct serrations; teeth of outer ceratobranchial-1 gill rakers well-developed on distal halves of rakers only; anterior dorsal-fin pterygiophore formula $S / S / S+3 / 1+1 / 1 / 1 / 1 / 1 / 1+1 / 1 / 1 / 1+1$; dorsal-fin spines stout and pungent; anterior anal-fin pterygiophore formula $3 / 1+1 / 1 / 1+1$; anal-fin spines stout and pungent, second spine stouter than third; pelvic-fin spine moderately stout and pungent; second segmented pelvic-fin ray longest; caudal fin rounded; vertebrae $10+16$; epineurals 14 ; epurals 3 .

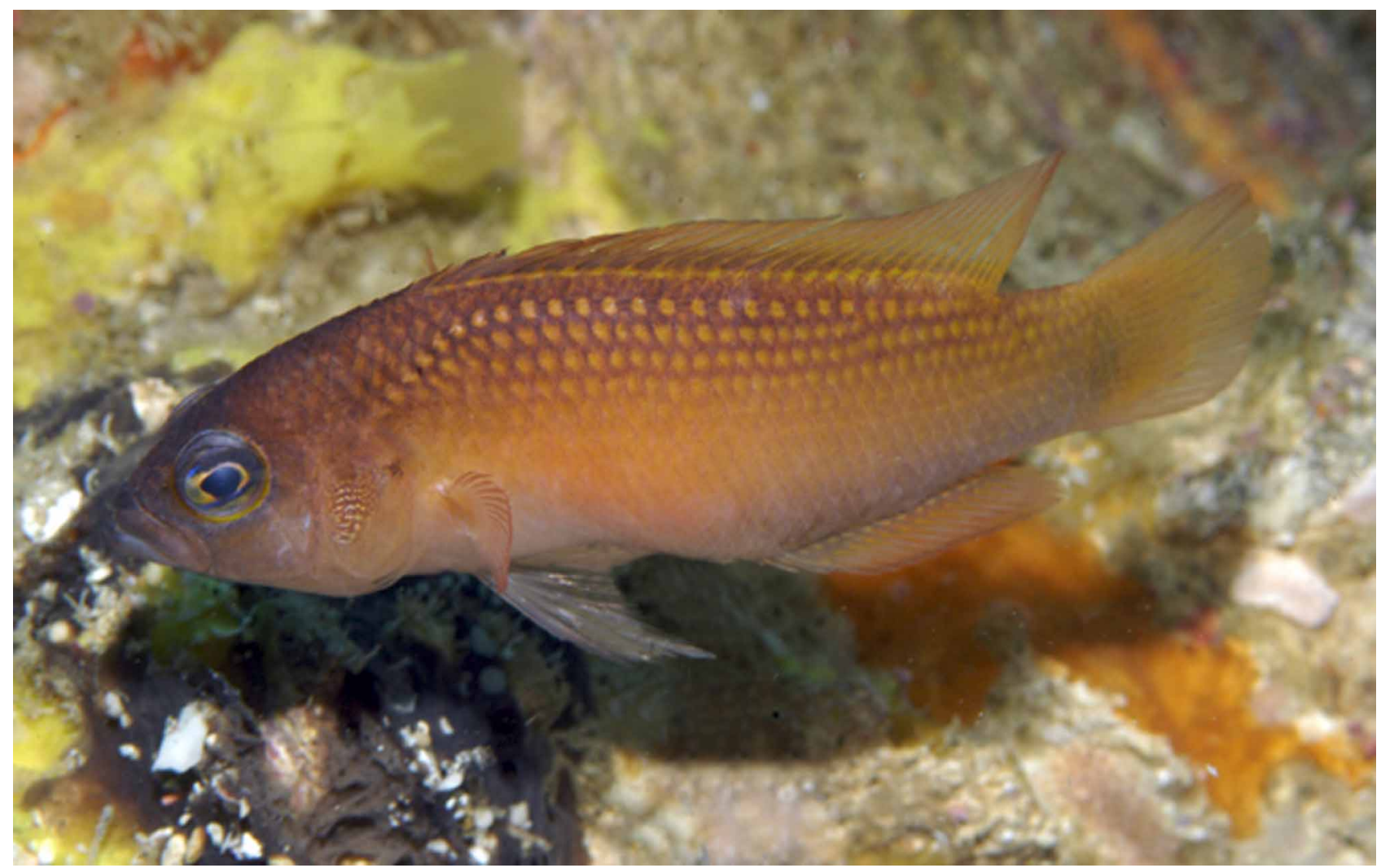

FIGURE 4. Pseudochromis rutilus, ZMB 20568, holotype, 55.0 mm SL, Buyuk, Nusa Penida, Indonesia (photo by M.V. Erdmann). 
Upper jaw with 2 pairs of curved, enlarged caniniform teeth anteriorly, and 6 (at symphysis) to 3 (on sides of jaw) inner rows of small conical teeth, outermost of rows of conical teeth much larger and more curved than inner rows; lower jaw with 3 pairs of curved, enlarged caniniform teeth anteriorly, and 5 (at symphysis) to 1 (on sides of jaw) inner rows of small conical teeth, teeth on middle of jaw slightly larger and curved; vomer with 1-2 rows of small conical teeth, forming chevron; palatines with 1-3 rows of small conical teeth arranged in elongate, suboval patch, anterior part of tooth patch more-or-less contiguous with posterolateral arm of vomerine tooth patch; ectopterygoid edentate; tongue moderately pointed and edentate.

As percentage of SL: head length 24.9; orbit diameter 9.5; snout length 6.9; fleshy interorbital width 6.5; bony interorbital width 4.7 ; body width 14.7 ; snout tip to posterior tip of retroarticular bone 15.3 ; predorsal length 35.3 ; prepelvic length 34.0; posterior tip of retroarticular bone to pelvic-fin origin 19.6; dorsal-fin origin to pelvic-fin origin 34.7; dorsal-fin origin to middle dorsal-fin ray 39.1; dorsal-fin origin to anal-fin origin 47.6; pelvic-fin origin to anal-fin origin 30.0; middle dorsal-fin ray to dorsal-fin termination 24.0; middle dorsal-fin ray to anal-fin origin 33.3 ; anal-fin origin to dorsal-fin termination 36.7; anal-fin base length 26.4; dorsal-fin termination to anal-fin termination 18.7; dorsal-fin termination to caudal peduncle dorsal edge 10.2; dorsal-fin termination to caudal peduncle ventral edge 20.4; anal-fin termination to caudal peduncle dorsal edge 23.6; anal-fin termination to caudal peduncle ventral edge 12.4; first dorsal-fin spine 3.1; second dorsal-fin spine 6.5; third dorsal-fin spine 8.5; first segmented dorsal-fin ray 13.3; fourth last segmented dorsal-fin ray 17.6; first anal-fin spine 2.2; second anal-fin spine 5.3; third anal-fin spine 7.1; first segmented anal-fin ray 11.2; fourth last segmented anal-fin ray 17.3; third pectoral-fin ray 17.5; pelvic-fin spine 12.2; second segmented pelvic-fin ray 26.9; caudal-fin length 28.2.

Live coloration (based on a photograph of the holotype): Head purplish to reddish brown, becoming pale orange ventrally; orbital rim narrowly bright yellow, bordered around posterior and ventral edge with blue curved bar, this extending to middle of upper lip, then along ventral edge of first infraorbital to snout; cheeks tinged with pale blue; opercular flap with indistinct dusky grey spot; anterior portion of operculum pale blue with short purplish red horizontal lines; iris purplish brown dorsally, yellow ventrally, with bright blue sub-oval ring around pupil; body purplish to reddish brown dorsally, bright orange-yellow to gold on flanks, becoming pale pink to pale purple ventrally; scales of anterior lateral line and next 4-5 scale rows below each with large gold spot, these becoming less distinct and grading into background coloration on mid-sides of body and caudal peduncle; scales of nape and body above anterior lateral line each with indistinct yellow basal spot; dorsal fin purple basally, the remainder of fin pinkish hyaline with narrow purple margin; fin rays bright yellow, with large bright yellow spot at the base of each ray; anal fin similar to dorsal fin, except with spots at base of each fin ray pale pink, and with row of bright yellow spots along distal edge of purple basal stripe; caudal fin bright yellow, greyish yellow on central part of fin base, with distal third of fin abruptly pinkish hyaline; pectoral fins pinkish hyaline, bright yellow on fin base; pelvic fins pinkish hyaline, pale mauve anteriorly and distally.

Preserved coloration: pattern similar to live coloration, purplish to reddish brown, blue and grey markings on head, body and fins becoming greyish brown; lower part of head and body pale yellow; orange, gold and yellow spots conspicuous on body, becoming pale yellow.

Habitat and distribution. Known only from the holotype, this species was observed and collected at $70 \mathrm{~m}$ depth on a current-swept, steep slope on the north face of Nusa Penida island in the Lombok Strait off Bali. Though only one specimen was collected, several individuals were observed in the near vicinity, all of them darting under low, rocky overhangs and larger coral rubble pieces on this current-swept, low-relief slope.

Comparisons. Pseudochromis rutilus is ambiguous at couplet 50 of Gill's (2004) key to Pseudochromis species, having the relatively deep body of 50a (P. fowleri Herre 1934), but the relatively short anal-spine three of 50b (P. andamanensis Lubbock 1980, P. aurulentus Gill \& Randall 1998, P. flavopunctatus Gill \& Randall 1998, P. litus Gill \& Randall 1998, P. marshallensis Schultz 1953, P. pylei Randall \& McCosker 1989, and P. reticulatus Gill \& Woodland 1992). Thus, these two characters in combination (dorsal-fin origin to pelvic-fin origin $34.7 \%$ SL; third anal-fin spine $7.1 \%$ SL) are useful to distinguish P. rutilus from species at couplet 50. It is further distinguished from $P$. fowleri in having III,26 dorsal-fin rays (versus III,23-25), 25 predorsal scales (versus 13-18), which extend anteriorly to midway between the anterior and posterior nostrils (versus to point ranging from vicinity of anterior AIO pores to midway between posterior nasal pores and posterior nostrils), and a rounded caudal fin (versus emarginate). Pseudochromis oligochrysus also falls beyond couplet 50 of Gill's key. It is readily distinguished from $P$. rutilus in having more segmented anal-fin rays (16 versus 14).

Remarks. The specific epithet is from the Latin, meaning reddish gold, and alludes to the purplish red and yellow to gold live coloration. 


\section{Acknowledgements}

The authors would like to thank the following agencies for supporting the rapid biodiversity assessment of Nusa Penida which led to the discovery of these two species: the Indonesian Ministry of Research and Technology, the Indonesian Institute of Sciences, the Ministry of Marine Affairs and Fisheries, the Bali Department of Nature Conservation (BKSDA), the Klungkung regional government, and Conservation International. Michael Cortenbach and Sven Fautz at Bali Dive Academy provided excellent logistical support for the survey, as did Patti Seery and the crew of the Silolona during the subsequent survey of the Pantar-Alor area. Iwan Dewantama and Ketut Sarjana Putra of Conservation International are owed special thanks for their efforts in arranging the Nusa Penida assessment. We thank A. Hay and J. King for providing radiographs, and R Hadiaty and A. Rosichon for curation of the holotype specimens. Finally, we thank the Paine Family Trust for support of the field work that led to these discoveries.

\section{References}

Allen, G.R., Gill, A.C. \& Erdmann, M.V. (2008) A new species of Pseudochromis Rüppell (Pisces: Pseudochromidae) from Papua Barat Province, Indonesia. Aqua, International Journal of Ichthyology, 13, 155-162.

Gill, A.C. (2004) Revision of the Indo-Pacific dottyback fish subfamily Pseudochrominae (Perciformes: Pseudochromidae). Smithiana Monograph, 1, 1-214, pls 1-12.

Gill, A.C. \& Allen, G.R. (2004) Pseudochromis lugubris and P. tonozukai, two new dottyback fish species from the Indo-Australian Archipelago (Perciformes: Pseudochromidae: Pseudochrominae). Zootaxa, 604, 1-12.

Gill, A.C. \& Allen, G.R. (2011) Pseudochromis erdmanni, a new species of dottyback with medially placed palatine teeth from Indonesia (Teleostei: Perciformes: Pseudochromidae). Zootaxa, 2924, 57-62.

Gill, A.C., Allen, G.R. \& Erdmann, M.V. (In press) Two new species of striped Pseudochromis from the Philippine Islands and Indonesia, with a redescription of $P$. colei (Teleostei: Pseudochromidae). Zootaxa

Gill, A.C., Erdman, M.V. \& Allen, G.R. (2009) Pseudochromis matahari, a new species of dottyback (Perciformes: Pseudochromidae) from Halmahera, Indonesia. Aqua, International Journal of Ichthyology, 15, 45-48.

Gill, A.C. \& Randall, J.E. (1998) Five new species of the dottyback genus Pseudochromis from Indonesia (Teleostei: Pseudochromidae). Revue française d'Aquariologie Herpétologie, 25, 17-26.

Gill, A.C. \& Williams, J.T. (2011) Description of two new species of Pseudochrominae from northern Palawan and Mindoro, Philippine Islands (Teleostei: Perciformes: Pseudochromidae). Zootaxa, 3140, 49-59.

Gill, A.C. \& Woodland, D.J. (1992) Description of a new dottyback of the genus Pseudochromis (Pisces: Pseudochromidae) from Western Australia. Records of the Australian Museum, 44, 247-251.

Gill, A.C. \& Zajonz, U. (2011) Pseudochromine and pseudoplesiopine dottyback fishes from the Socotra Archipelago, Indian Ocean, with descriptions of two new species of Pseudochromis Rüppell (Perciformes: Pseudochromidae). Zootaxa, 3106, $1-23$.

Lubbock, R. (1980) Five new basslets of the genus Pseudochromis (Teleostei: Pseudochromidae) from the Indo-Australian Archipelago. Revue Suisse de Zoologie, 87, 821-834.

Randall, J.E. \& McCosker, J.E. (1989) Pseudochromis pylei (Teleostei: Perciformes; Pseudochromidae) a new dottyback from Indonesia. Revue Française d'Aquariologie Herpétologie, 16, 7-10.

Schultz, L.P. (1953) Family Pseudochromidae. In: Schultz, L.P., Herald, E.S., Lachner, E.A., Welander, A.D. \& Woods, L.P., Fishes of the Marshall and Marianas Islands. Volume 1. Families from Asymmetrontidae through Siganidae. United States National Museum Bulletin, 202, 380-411, pl. 33a. 